\title{
Correction to: The Surgical Legacy of Randolph Lee Clark Jr, MD: First Surgeon-in-Chief and Director of University of Texas MD Anderson Cancer Center I. Training and Surgical Practice Before Recruitment to University of Texas MD Anderson Hospital
}

\author{
Charles M. Balch, MD, FACS, FASCO \\ Department of Surgical Oncology, University of Texas MD Anderson Cancer Center, Houston, TX
}

\section{CORRECTION TO:}

ANN SURG ONCOL

HTTPS://DOI.ORG/10.1245/S10434-020-09511-5

The electronic supplementary material for this article has been updated.
Publisher's Note Springer Nature remains neutral with regard to jurisdictional claims in published maps and institutional affiliations.

The original article can be found online at https://doi.org/10.1245/ s10434-020-09511-5.

(C) Society of Surgical Oncology 2021

Published Online: 2 February 2021

C. M. Balch, MD, FACS, FASCO

e-mail: cmbalch@mdanderson.org 